DOI https://doi.org/10.18551/rjoas.2018-07.13

\title{
PASURUAN POLICE RESORT TRAFFIC STRATEGY TOWARDS OVERCOMING HIGHWAY ACCIDENTS BY UNDERAGE STUDENTS
}

\author{
Amalia Mellysa \\ Postgraduate School, Airlangga University, Indonesia \\ E-mail: mellysa61@gmail.com
}

\begin{abstract}
The purpose of this research is to analyze the function and strategy of Pasuruan Police to handle accident rate by motor vehicle underage user. The results showed that the level of motor vehicle usage by children in Pasuruan Police area increased significantly, especially high schools, where factors affecting the increase of accidents are family, school, environmental, and self-emotional factors.
\end{abstract}

\section{KEY WORDS}

Strategy, traffic, accident, child.

The increasing complexity in transportation need makes people consider every option to fulfil their expectation. Unfortunately, not all cars' driver and motorcycle riders are legally able to operate their vehicle in the perspective of law. There are many underage students who, is not legal yet, wish to use the vehicles. But, in fact, they are riding and driving their vehicles freely on highway road. These underage drivers often cause accident among others. The accidents are mostly caused by their unstable psychology, the mental and physical condition, and their improper and careless characters. Moreover, in some cases, it is also as result of their lack of knowledge on traffic rules and signs. That is why, in this case government and police traffic must build children protection as victims and violation actors.

Factually, senior and junior high students are still in process of "who am I" seeking phase. They are easy to provoke within simple things, they are fragile to violate and broke the law, even though the norms among society. Nowadays, we often see these student ride their motorcycle in rush and dangerous way. They do not bring identity card of their vehicle and also driving license as their age is still not yet fulfil the requirements of it. Even, they often ride within three people in one motorcycle. In fact, most of these students receive the permission from their parents to use the vehicles. Even though, the parent realised that it is illegal and dangerous to let their children to drive or ride. The parents know that their children are not yet 17 years old and have no driving license. In this case, family becomes the smallest and closest unit to educate their youth members. That is why; parents must not permit their children to use the conveyance. The number of highway road accidents in Pasuruan regency in 2014-2016 is relatively in high rate as stated on the table below.

Table 1 - The number of highway accident in Pasuruan Jurisdiction

\begin{tabular}{|c|c|c|c|c|c|c|}
\hline \multirow{2}{*}{ Victims' Status } & \multicolumn{5}{|c|}{ Years } & \multirow{2}{*}{ Total } \\
\cline { 2 - 7 } & 2012 & 2013 & 2014 & 2015 & 2016 & 39 \\
\hline Death & 119 & 53 & 47 & 34 & 16 & 292 \\
\hline Serious Injuries & 45 & 27 & 17 & 16 & 47 & 152 \\
\hline Light Injuries & 993 & 620 & 552 & 631 & 517 & 3313 \\
\hline Jumlah & 1157 & 700 & 616 & 681 & 603 & 3757 \\
\hline
\end{tabular}

Source: Pasuruan Police Resort 2016.

From the data above, we can conclude that the total number of accidents on Pasuruan jurisdiction of 2012-2016 is 3.757 cases. The light injuries victims reach 3313 people, the serious injuries are 152 people, while the death victims are on 292 people. 


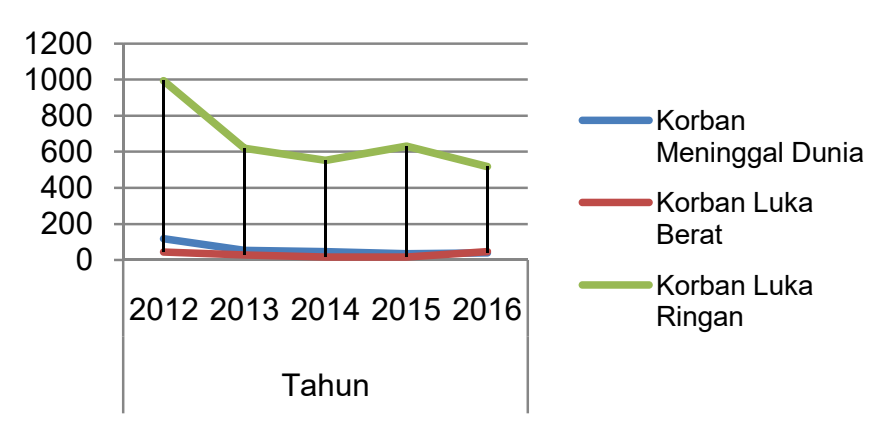

Figure 1 - The number of highway accident in Pasuruan Jurisdiction

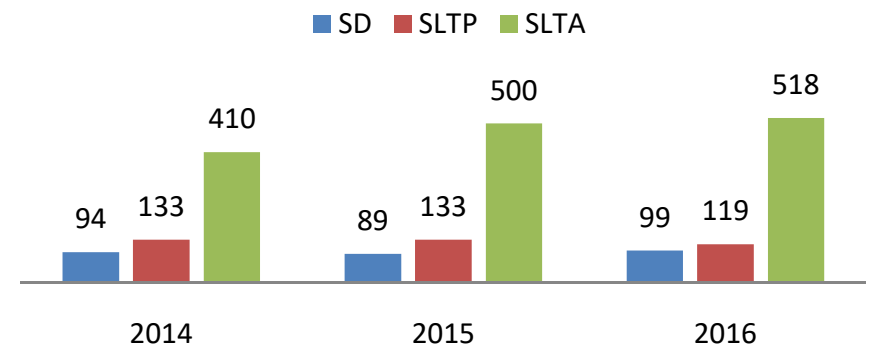

Figure 2 - The underage subject of traffic violation shortened by education level

From the data above, we can conclude that the accidents by underage students within 3 years 2014-2016 are 2.095 in total, whereas the elementary school students covers 282 students, the junior high is 385 cases, and the senior high students gather 1.428 cases. This supports the statement that any accidents cause or caused by underage students are in high numbers. It is very important for Pasuruan police to take actions.

Accordance with the violation of Indonesian Law number 22 of 2009 about traffics and transportation by students, there must be a prevention action to minimise the issues. The strategy could implement preventive or repressive way. Preventive strategy prevents the students to avoid disobedience and obey the law to minimise the civil action. Meanwhile, the repressive action must be implemented directly as the violation has been occurred. The institution who has duty and right to maintain in such cases is the traffic police which is known as Polantas in Indonesia.

Polantas has right and authorities to take care of the cases which violate the Indonesian law number 22 of 2009 about Traffics and Transportation. According to Indonesian Police Leader Regulation number 23 of 2010 about the organisation structure and administration work on Police Resort and Sector level article 59, Polantas has duties to control, guard, escort, patrol of traffics, and educate the society, registration and verification service for vehicles and users, and the identification of highway accidents, and the law enforcement of traffic regulation which has been implemented.

From the facts above, the police must be able to show its strategy in overcoming and preventing the number of underage student driving accidents.

\section{METHODS OF RESEARCH}

The research method used in this study is qualitative method. The setting of study takes place on the jurisdiction of Pasuruan police resort. Because, there are high numbers of underage children accidents occurred in this area. The informant of this study is vice head of Pasuruan Police Resort, Head Division of Traffic Pasuruan resort police, the personnel of traffic police of Pasuruan regency, and the student underage drivers. 


\section{RESULTS AND DISCUSSION}

The Number of Motor Vehicle Usage and the Influence Factors of Underage Student Accidents in Pasuruan Police Resort Jurisdiction. It has been found that there are many drivers who are not yet old enough to use the vehicle in reality especially towards senior high school students. According to the subject case of Resort Police data, it could be displayed as follow:

Table 1 - The underage subject of traffic violation shortened by education level

\begin{tabular}{|c|c|c|c|c|c|}
\hline No & Education & 2014 & 2015 & 2016 & Total \\
\hline 1. & Elementary & 94 & 89 & 99 & 282 \\
\hline 2. & Junior High & 133 & 133 & 119 & 385 \\
\hline 3. & Senior High & 410 & 500 & 518 & 1,428 \\
\hline
\end{tabular}

Source: Pasuruan Police Resort 2016.

From the data above, we can conclude that the accidents by underage students within 3 years 2014-2016 are 2.095 in total, whereas the elementary school students covers 282 students, the junior high is 385 cases, and the senior high students gather 1.428 cases. This supports the statement that any accidents cause or caused by underage students are in high numbers. It is very important for Pasuruan police to take actions.

The development of parenting pattern in Indonesia has been increased. This increasing is developed and changed. For example, the technology development has helped many children, it served any kind of information even when the information is not yet needed by them. The knowledge of parents on the age limit to drive vehicle is very important. Because, in driving process, the decision making is very tight, the driver must not only think of their safety but also other safety. Moreover, on that age, the children is already assumed to have stable emotion.

In highway condition, the driver is expected not to be easily provoked. There are many parents who do not yet understand that risk. They finally give permission for their underage children to drive the motor vehicle. The movement of this parenting pattern must be quickly resolved and slowly changed as family is the very first council for children. Parents, as model role, must able to provide good example for their children, they must take a good care of them. The parent must possess enough information about the traffic law and signs within safety riding. Thus, children would receive enough knowledge of their duty and rights as drivers in highway riding.

As one of education and knowledge media for the children, school is very important to teach them about discipline. Unfortunately, there are some schools that permit their students to bring their motor vehicle to school. It inspires them to ride motor vehicle while going to their school, it is also caused by there is no socialisation towards legal and safety riding from the related institution.

High speed driving in rush and dangerous way become a characterisation among society. There are many drivers who drive in high speed including the underage children. That decision often causes many traffic accidents. The demand of this driving behaviour by adults inspires and copied by children as they saw adult as role model within social life.

Children or adolescents also play a role in driving offenses. Factors of association and lifestyle can affect underage children who are not yet emotionally stable. Adolescents are recognized as a stage of development that is still in search of identity. The occurrence of changes in aspects of emotionality in adolescents one of them occurred as a result of physical and hormonal changes. This all demands new control and regulatory capabilities for their behaviour. At this time teenagers tend to be a lot of moody and unpredictable, behaving harshly to cover the lack of confidence. Anger usually happens and tends to be intolerant of others and wants to always win by them, start observing their parents and teachers objectively. In adolescents aged 15-18 years, adolescent rebellion is a universal expression and change from childhood to adulthood. Many adolescents experience conflict with their parents. A number of studies on teen emotions show that their emotional development 
depends on factors of maturity and learning factors. Maturity and learning are closely intertwined with each other in influencing emotional development.

The Function and Strategy of Pasuruan Police Resort to Control the Number of Highway Accidents by Underage Teenager Students. The report conducted by people to resort police was meant to measure of how the ability of the police to handle in such cases. Moreover, the report could determine the working performance of the police instead to handle highway accidents, the police is meant to identify and fulfil the people's demand who experience the case as the user of service itself.

Determining the first action when the police arrive at crime scene is very crucial to judge the suspect's responsibility. The civil sanction is given to suspect who commit of what they did to determine their mistake.

In accident, there will be victims who really need help from the police. In this case, the pasuruan resort police is very helpful to help the victims by carrying them to the nearest hospital for first aid. The victims need both direct help and indirect help from the police. In some cases, the victims may receive direct help from the local people if the condition is sustaining enough.

Crime scene identification is one of repressive action. The police has authority to check the truth of the chronological accidents within its technical requirements and the condition of vehicle itself.

Socialisation of the rule of riding and the safety riding when riding at highway road is used as one of preventive action by the police. Police or other related institution can use the brochure media to spread the awareness where youth gather. Not only to obey the mandatory of regulation but also the consequence of the youth if they choose to violate and break the law such as not having the driving license. Brochure is the most effective media to spread the idea because of its small size and easy to store.

Civil law and fine are one of attempt to commence repressive action. But, as the subject is still underage, the law of women and children must considered include in this option, for instance if the accident caused by the underage results in death victims, there will be a lawsuit subsidiser as stated in article 281 of LLAJ Law, or the judges are also able to use article 30 of LLAW law. In general, the civil sanction committed for the underage teenager, in maximum, must be a half for the adults' one as stated in article 81 point 2 of SSPA law.

But, the consideration of law for underage teenagers is till implemented which is determined by the age, background of the case, the mental condition and alibi mode of the case. Because of those factors, the teenagers will be accompanied $n=b y$ their parents or proxies during the court process.

The Obstacles Faced By Pasuruan Traffic Police Resort in Overcoming the Traffic Accidents on Its Jurisdiction Area. Eventually, every resort police of Indonesia must have Police Goes to School program, the program is done by visiting the school to socialise the students of ho to wear helmet in proper way when they are being picked up by their parents. Moreover, safety riding is one of feature of the program. Unfortunately, the program did not reach the maximum outcome. The lack of financial condition and lack of personnel prevent the program to achieve its vision. Therefore, the program explains the ethics and regulation of driving within traffic condition. This education plays important role in developing and increasing the knowledge of society. Because, informing people by providing training is easier than other methods received by society. The behaviour which possessed knowledge foundation will be must last longer. In the other hand, any behaviour customs without enough knowledge will result in short term action.

Nowadays, the motor cycle usage is very popular among underage students to go to school as private transportation. Even, there are students of elementary school and first grade of junior high who already grant permission from their parents to ride motorcycle. This action is not correct from any perspectives, especially from law point of view. Civil regulation informs people that the minimum age of adult age category is 16 (article 45, 47 of Criminal Code). 
Children less than 16 years old are still the responsibility of their parents. At age of 16, this phase is a period where adolescents experience emotional instability and feelings. They tend to try new things that need to be watched and given attention by parents, teachers, and society to avoid negative behaviours.

\section{CONCLUSION AND SUGGESTIONS}

According to the previous discussion, the conclusions are as follow:

The amount of motor vehicle usage by underage students in jurisdiction of Pasuruan resort Police is significantly increasing especially for senior high school category. Meanwhile, the factor that influence increasing number of accidents by underage students on Pasuruan resort police jurisdiction are family factor which still permit their children to use motor vehicle, school factor, environment, and unstable emotion factor. Those factors and accidents lead Indonesian police, and pasuruan resort police as one of part of it, suggest that underage teenagers are not allowed to possess driving license and to use vehicle motor.

The resort police function to handle the accidents committed by underage teenagers are to receive the reports as one of public service, visiting the crime scene, helping the victims, identifying the chronology of the traffic accidents. The strategy of Pasuruan resort police to control the accident by preventive and repressive action. The police hold socialization into society by spreading the brochure, coordinating with schools by using I Love Student With Pak Sakera tagline.

The obstacles faced by Pasuruan Police in dealing with traffic accidents in Pasuruan District Police is not yet maximum result of Police Goes to School program by Dikmas Lantas Pasuruan Police, because there is no special budget for Dikmas and constraint of lack parents' awareness of children not to allow underage school children to drive motor vehicles.

Based on the conclusions, the following suggestion will be as follow:

Suggestion for School. The school can have initiation to put traffic knowledge as one of their academic learning program. It also could commence a corporation with other institution such as Dikmas and public relation of Pasuruan resort police.

Suggestion for Pasuruan Dikmas. Improving coordination and understanding between parents and police could be one of good attempt. Thus, the parents must aware of their responsibility to take their children to school by facilitating for their children to arrive at school. They can choose public transportation or bicycle. They must not permit their children to use motor vehicle as it is one of act to brake and violate the law.

Suggestion for Pasuruan Resort Police. There must be more financial administration value for police goes to school program which is already implemented by Pasuruan Dikmas resort police. Thus, the socialisation of I Love Student with Pak Sakera (I love cycling to School) program will be optimally implemented.

\section{REFERENCES}

1. Anggalia Putri Permatasari. (2011). Konsep Strategi dan Kebijakan Penanggulangan Terorisme di Indoenesia. Jurnal Kajian Terorisme dalam Keamanan Internasional Departemen IImu Hubungan Internasional. FISIP UI.

2. Al Qurni, Isa. (2013). Analisis Rawan Kecelakaan Lalu Lintas di Jalan Nasional Kabupaten Kendal. Jurnal Universitas Negeri Semarang.

3. Aroma, Iga Serpianing dan Dewi Retno Suminar. (2012). Hubungan Antara Tingkat Kontrol Diri Dengan Kecenderungan Perilaku Kenakalan Remaja. Jurnal Psikologi Pendidikan dan Perkembangan, Vol. 1, No. 2, Juni.

4. Freitas, Joao Mario, Muhammad Yusuf, Petrus Wisnubroto. (2013). Strategi Pemasaran Guna Meningkatan Volume Penjualan Dengan Pendekatan Technology Atlas Project Method. Jurnal Rekavasi, Vol. 1. No. 1.

5. Gumarso, Singgih D. (1988). Psikologi Perkembangan Anak dan Remaja. Jakarta: Gunung Mulia. 
6. Hamidi.(2010). Metode Penelitian dan Teori Komunikasi. Malang: Universitas Muhammadiyah Malang Press.

7. Hidayati, Annisa.,Lucia Yovita Hendrati. (2016). Analisis Risiko Kecelakaan Lalu Lintas Berdasar Pengetahuan, Penggunaan Jalur, dan Kecepatan Berkendara. Jurnal Berkala Epidemiologi, Vol. 4. No. 2, Mei, pp: 275-287.

8. Huda, D. (2013). Pertumbuhan Fisik dan Perkembangan Intelek Usia Remaja. Al-'Ulum, Vol. 2.

9. Kartini-Kartono. (1989). Psikologi Anak (Psikologi Perkembangan). Bandung: Mandar Maju.

10. Marsaid, M. Hidayat dan Ahsan. (2013). Faktor yang Berhubungan dengan Kejadian Kecelakaan Lalu Lintas Pada Pengendara Sepeda Motor di Wilayah Polres Kabupaten Malang. Jurnal Ilmu Keperawatan, Volume 1, No. 2, Nopember, hlm. 98-112.

11. Murti, Rialiskan Teja dan Imam Muthohar. (2012). Evaluasi Kinerja Rambu Pembatasan Kecepatan Sebagai Upaya Mendukung Aksi Keselamatan Jalan. Jurnal Transportasi Vol. 12 No. 3 Desember.

12. Primulyani,Atika Novy. (2011). Fenomena Pengendara Motor di Bawah Umur di Jalan Kesatrian Kidul Kota Magelang.

13. Sakti, Bayu Pramdya Kurniawan. (2012). Analisis Penentuan Lokasi Rawan Kecelakaan Lalu Lintas di Jalur Utama Kabupaten Jember (Metode Pencacahan Indikator Kerawanan). Jurnal Teknik Sipil Universitas Jember.

14. Sari,Dewi Anjar. (2015). Konseling Melalui Media Telekomunikasi Telepon (Studi Kasus di Tesa 129 Pusat Pelayanan Terpadu Perempuan dan Anak "Rekso Dyah Utami" Daerah Istimewa Yogyakarta). Jurnal Komunikasi Universitas Islam Negeri Sunan Kalijaga Yogyakarta.

15. Setiawan, Jerry. (2014). Latar Belakang Perilaku Remaja Dalam Mengemudikan Sepeda Motor Tanpa Surat Izin Mengemudi (Studi Kasus Pelajar SMPN 11 Kota Samarinda).eJournal Ilmu Sosiatri. hal. 1-15.

16. Sugiyanto, Gito dan Mina Yumei Santi. (2015). Karakteristik Kecelakaan Lalu Lintas dan Pendidikan Keselamatan Berlalu Lintas Sejak Usia Dini: Studi Kasus di Kabupaten Prbalingga. Jurnal IImiah Semesta Teknika, Vol.18No. 1, Mei.

17. Suryani,Yuni, Holilullaoh dan Yunisca Nurmalisa. (2014). Sikap Orang Tua Terhadap Pengendara Motor dibawah Umur di Lampun Selatan. Jurnal Psikologi Pendidikan Lampung Selatan.

18. Tarigan, Mattias Mauriz. (2014). Peran Polisi dalam Mencegah Anak di Bawah Umur Mengendarai Kendaraan Bermotor di Jalan Umum Daerah Istimewa Yogyakarta.

19. Undang-Undang Republik Indonesia Nomor 22 Tahun 2009 Tentang Lalu Lintas dan Angkutan Jalan.

20. Undang-Undang Nomor 11 Tahun 2012 Tentang Sistem Peradilan Pidana Anak. 